\title{
Climate change and COVID-19: shared challenges, divergent perspectives, and proposed collaborative solutions
}

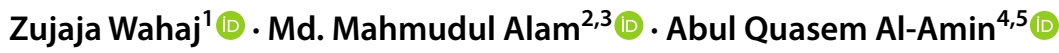

Received: 4 October 2021 / Accepted: 25 December 2021 / Published online: 6 January 2022

(c) The Author(s), under exclusive licence to Springer-Verlag GmbH Germany, part of Springer Nature 2022

\begin{abstract}
Pandemics leave their mark quickly. This is true for all pandemics, including COVID-19. Its multifarious presence has wreaked havoc on people's physical, economic, and social life since late 2019. Despite the need for social science to save lives, it is also critical to ensure future generations are protected. COVID-19 appeared as the world grappled with the epidemic of climate change. This study suggests policymakers and practitioners address climate change and COVID-19 together. This article offers a narrative review of both pandemics' impacts. Scopus and Web of Science were sought databases. The findings are reported analytically using important works of contemporary social theorists. The analysis focuses on three interconnected themes: technology advancements have harmed vulnerable people; pandemics have macro- and micro-dimensions; and structural disparities. To conclude, we believe that collaborative effort is the key to combating COVID-19 and climate change, while understanding the lessons learnt from the industrialised world. Finally, policymakers can decrease the impact of global catastrophes by addressing many socioeconomic concerns concurrently.
\end{abstract}

Keywords Climate change $\cdot$ COVID-19 $\cdot$ Pandemic $\cdot$ Impacts $\cdot$ Collaborative solutions

\section{Introduction: a mosaic of uncertain contexts}

"No longer were there individual destinies; only a collective destiny, made of plague and emotions shared by all" (Camus 1948: 167). Set in the city of Oran, Albert Camus's

Responsible Editor: Lotfi Aleya

Abul Quasem Al-Amin

qalamin@uwaterloo.ca

Zujaja Wahaj

zujaja.wahaj@nbs.nust.edu.pk

Md. Mahmudul Alam

rony000@gmail.com

1 NUST Business School (NBS), National University of Sciences \& Technology (NUST), Islamabad, Pakistan

2 School of Economics, Finance \& Banking, Universiti Utara Malaysia, Kedah, Sintok, Malaysia

3 Centre for Asian Climate and Environmental Policy Studies (CACEPS), Windsor, ON, Canada

4 Department of Geography and Environmental Management, University of Waterloo, ON, Waterloo, Canada

5 Department of Development Studies, Daffodil International University, Dhaka, Bangladesh book The Plague describing a fictional plague in the 1940s opens many windows to understand what it means to experience a pandemic. Initially, as Camus narrates, the plague welcomes an aloof response from the residents of Oran, the government does not warn people about the spreading disease, the state of denial stubbornly remains, and when people are dying a realisation is made of their "collective destiny". Given the outbreak of COVID-19, The Plague is no longer an allegory, as it starkly parallels the multiple realities of how governments and citizens are responding to live with the disease. The Plague resonates today with what people are witnessing: the ever-burgeoning COVID19 virus transmission and death rates-first especially in the initial months of the virus, and later in the second wave of its more stringent strains experienced around the globe. In this scenario, hospitals do not have the resources or paramedic staff to cope with the situation and they are on the point of exhaustion (Khalid and Ali 2020). There are delays and changes in government strategies other than building herd immunity to deal with the virus (Scacmbler 2020), and citizens opposing the containment measures in many parts of the world (Golechha 2020; Reuters 2020). The only exception are those countries that were able to demonstrate the 
readiness of handling the pandemic due to good governance and well-developed health systems.

In the midst of these conditions of modern COVID-19 times, however, there are other shades woven into the everyday fabric of people's lives. In particular, COVID-19 has put the more-than-human aspects of this picture in the foreground; collective struggles and empathy have remained central to their experiences (Prainsack 2020; United Nations 2020), especially ever since social distancing as a prevention measure was implemented by many of the world's governments. Yet, for many others, the everyday trajectories of surviving COVID-19 are shaped by oppression and discrimination (The Tribune 2020; Laurencin and Walker 2020), thereby partially challenging Camus's notion of everyone having a "collective destiny". Opposed to the notion of "collective" that frames "all" or "everyone" sharing common suffering as suggested by Camus, the race theorist Kimberlé Crenshaw's concept of "intersectionality" offers us a useful lens to establish a point of departure from the cliché we are all in this together!

In other words, wrongly signifying a holistic notion of everyone forming similar or collective experiences in the face of this pandemic. The reality is very much different. A close focus on the subtle nuances of for example race, class, gender, caste, religion, ethnicity, etc., allows us to view how inequality and power are structured differently for a variety of groups of people, who are entrenched in the interlocking systems of oppression when viewed from their demographic characteristics and location (Crenshaw 1989). The COVID19 pandemic has amplified and put under the spotlight more than ever before the crevices in structural inequalities and the differential, exclusionary experiences of various communities who are socially disadvantaged (Marmot 2020). Thus, the historic vulnerabilities of gender, class, race, caste, etc., coupled with the vulnerabilities arising out of the COVID19 pandemic have left the poorest doubly marginalised.

From the outset, though we envisage COVID-19 bringing various hues of individual experiences, potentially coalescing in forming a collage of trajectories surrounding the everyday survival of this virus, and therefore making a compelling case to find a solution specific to their predicament of living under the shadow of COVID-19. For us as commentators, their predicaments prompted us to contemplate and propose possible solutions to manage and resolve the COVID-19 situation. Their predicaments of living with COVID-19 apparently demanded us to stop treating the virus as a standalone incident impacting on the lives of many and for which looking for a stand-alone solution would be myopic. Instead, the excursion into Camus's notion of The Plague on a broader canvass symbolises something "unknown to humanity", a "catastrophe" or a "calamity" to which human are eternally vulnerable. We, therefore, propose that at this precise moment in history there is a need for collaborative solutions to global catastrophes. To do so, we must broaden our imagination and find ways to save our present and the future. The passage below gives us hints for how to start anew so that future generations are saved:

Given long-term processes in much of social life, anticipating futures is absolutely essential. And once one is undertaking future thinking, then public bodies are central to that process. Indeed, they are often the key coordinator of the future-making process. So I suggest that future thinking is a major way of bringing the state and civil society back in from the cold, especially if the focus is upon social and not just technological futures (Urry 2016, 191).

Urry's book-What is the Future?-is a significant contribution to the debates on the mysteries of what lies ahead for us in the future. John Urry, a sociologist of the future wants us to consider questions of depletion, destruction, devastation and disappearance, so that collaborative effort are made to change the future. The decades of industrialisation have given birth to myriad activities geared towards the sustaining of capitalism, depletion of natural resources which is occurring at the same time and making worse climate change. These events are closely associated with health hazards, and disruptions at both the macro- and micro-levels. This calls for a close revisit of a couple of these pandemics to reach realistic and workable solutions that would leave this planet safely in the hands of future generations.

\section{Cartographies of pandemics of the current century: the intersections unveiled}

How we live, produce, and consume goods/services and resources is critical to understanding pandemics and saving the globe from future pandemics. The most recent pandemic, COVID-19, came at a time when the globe was already coping with climate change. 2019 was the second warmest year on record, with a $2^{\circ} \mathrm{F}$ rise in temperature, the highest since pre-industrial periods (Patz et al. 2020), when life was simpler and human civilisations did not destroy natural resources. Acknowledging a state of emergency to save the planet, the UNFCCC played a key role in preparing the governments to reduce their countries' $\mathrm{CO}_{2}$ emissions. This could be and still is achievable by shifting to the renewable energy system (De La Peña et al. 2022; Albert 2021). Indeed to stop global warming, a 22 Conference of Parties (COP22) attended by regional and world leaders was organised in 2016. The COP21 and the "Paris Accord" became a landmark in history when 186 nations promised to limit the global temperature rise to $1.5^{\circ}$ $\mathrm{C}$ for the following century. This landmark treaty provided an outline for how to mitigate climate change (Farid et al. 2016). These nations, which produce $96 \%$ of the total worldwide 
emissions, submitted pledges of emissions reduction and agreed on actions for assessing progress, as well as updating these pledges (Bodansky 2016; Falkner 2016; Le Quéré et al. 2016; Rogelj et al. 2016). However, nobody knew at that time that the planet would be hit in December 2019 by COVID-19; another enormous calamity that would halt all these commitments and efforts. Prioritising the urgency of saving human civilisation from COVID-19 resulted in the postponement of local and global efforts to combat climate change. To quote a few examples: the European Union came under pressure to postpone vital climate change initiatives; Poland suspended its carbon trading program; the Czech Republic abandoned the EU's landmark climate bill; and airline companies pressured regulatory bodies to delay emissions-cutting policies.

Using World War II as an analogy for a 'black swan' event (Chakraborty and Maity 2020; Renjen 2020), COVID-19 is discussed in the context of a rapidly changing economic landscape that presents us with a colossal challenge that is comparable to previous disastrous pandemics. Throughout history, pandemics have threatened human civilisation, for instance, The Plague of Athens, Black Death, Yellow Fever, Spanish Flu and the more recent pandemics, such as Ebola, SARS, and HIV/AIDS. The current COVID-19 pandemic shares common traits with earlier pandemics, for instance: (a) containment practices such as isolation, quarantine, limited interactions between people and communities, etc., were historically common measures (Abramowitz 2017); (b) evidence shows that the pandemics at any point in time have a toll on people's lives in addition to putting pressure on economic, social and political infrastructure (Dasgupta and Crunkhorn 2020), and (c) having to devise new and radically different health management systems (Lum et al. 2009; Siekmans et al. 2017; Shoman et al. 2017). COVID-19, however, departs from earlier health pandemics in a variety of ways. Lupton (2020) highlights three important changes from the 1980s HIV/AIDS pandemic. The first is a rapid worldwide spread, leaving governments, organisations, and individuals little time to respond. It's also important to note the longterm economic and social implications of quarantine and isolation, which have resulted in rising unemployment rates globally. The role of digital media and technology in this pandemic was unheard of 30 years ago when the HIV/AIDS pandemic began.

In this study, we present the climate change pandemic as being similar to COVID-19, and how to save our present and future generations. To begin, let us draw the commonalities between the two pandemics that dictate our imagination about finding solutions for both COVID-19 and climate change.

\section{Method and analytical approach}

This study was designed as a narrative review to collect evidence evidence-based impacts of both the pandemics, that is climate change and COVID-19. It was conducted in three basic steps, including literature search, screening and selecting articles, synthesis and analysis. For the first step of the literature search, keywords related to COVID19 impacts, climate change impacts, were identified, and then the synonyms for the word 'impacts' such as 'effects', 'consequences', 'outcomes', and 'results' were searched for relevant articles. In the second step, in accordance with these keywords, the search strategy was formed. The desired databases included Scopus and Web of Science. The mentioned databases were explored from 01 December 2019 to 30 September 2021 for COVID-19, whereas the search was extended to the period from 01 January 2009 to 30 September 2021 for climate change. This temporal framework was chosen because the effects of climate change on human and the world have been occurring for a considerably longer period of time than previously recognised.

In the second step of screening and selection of articles, all the searched material was entered into the Mendeley Reference Management Software. Following that, the publications were assessed for relevance to the subject of this review based on their titles, abstracts, and complete texts. The first two authors conducted the screening process independently, and the disagreements were referred to the third author. Once mutual consensus was reached, the final reference list was generated.

The third and final step was synthesis and analysis. All the search material that qualified to become part of the narrative review was critically examined qualitatively. The key findings were then reported analytically by employing the seminal works of significant social theorists of the nineteenth and twentieth centuries, such as Mills (1959), Giddens (1991), Beck (2010), Urry (2016), and Elliot (2018) to propose solutions with regard to engaging with climate change and COVID-19 pandemics simultaneously which is the key purpose of this paper.

In terms of limitations, the findings of this review paper cannot be generalised since the purpose of the narrative review is to capture and summarise what has already been written about a particular topic (Demiris et al. 2019; Paré and Kitsiou 2017). Nevertheless, the analysis reached after the narrative review has the global potential to offer collective solutions for governments, policymakers, and practitioners of climate change and public health in the years to come. 


\section{Findings and discussion}

The findings present three interrelated themes: technological advances have acted as a double-edged sword; both the pandemics have macro- and micro-dimensions; and structural inequalities that made life hard for vulnerable groups.

\section{Technological advances: a double-edged sword}

The roots of modern production and consumption patterns can be traced back to the beginning of the eighteenth century when a plethora of technological advances made the Industrial Revolution possible. Eventually, these led to rapid industrialisation, mass production and gave birth to the rise of capitalism. Wholesale manufacturing and surplus production became the governing principles for maximising profits. The search for new markets, cheap labour, and making quick profits became the norms of the day. The capitalist blinded by more and more profits became careless about material engineering of resources to the point of exhausting and depleting the Earth's complex ecosystem on which the future generations depended in order to stay alive and thrive. Rapid industrialisation and urbanisation led to an obvious outcome: the increasing trend of GHGs contributed mainly by the energy sector (IPCC 2014). During the twentieth century, it has been estimated that every year approximately thirty billion tons of $\mathrm{CO}_{2}$ from the combustion of fossils fuels enters the atmosphere. Subsequently, it has produced global warming and increased the frequency of environmental disasters, such as storms, floods, and droughts (IEA 2015). If left unchecked, global temperatures are projected to rise to well over preindustrial levels by about $3-4^{\circ} \mathrm{C}$ in 2100 with the danger of catastrophic heating (Christoff 2016). Such a development will have a huge impact on the sea surface temperature; sea level, Arctic sea ice and weather conditions. It is at the face of such adversities that the creation of new technologies takes place to produce effective solutions (Coccia 2017). Caution, however, still be taken to avoid damaging the remaining ecological biosphere (Holt 2021).

The 'climate crisis' is a human health emergency. Malnutrition, diarrhoea, respiratory illnesses, infectious diseases such as West Nile Virus, etc., are established health morbidities resulting from extreme climate conditions such as droughts, wildfires, smog, floods and hurricanes. Climate sensitive impacts on health and other spheres signal hundreds of billions of dollars having to be spent on them (Limaye et al. 2019). Coupled with the climate-related health emergency is the alarming health situation created by COVID-19, which shares similar roots and is also speedily transmitted across the globe. Nonetheless, the policymakers need to be altered towards devising a broader framework that is beyond the narrow boundaries of health and environment relevant explications only.

Modernity and post-modernity, which are essentially the non-conventional orders, leave us with the feeling that we are riding a juggernaut (Giddens 1991). Risks have become central to our everyday life. This leaves us having to live in an unpredictable modern world characterised by Beck (2010) as a 'risk society'. While writing in the context of climate change, he notes: "The greater the planetary threat, the less the possibility that even the wealthiest and most powerful will avoid it" (175). Thus, to live in an era of high modernity is to live in the active courting of risks. Moreover, the globalising tendencies of modernity are sketched out with dynamic influences of globalisation and changing lifestyles that have culminated in rapid urbanisation and burgeoning industrialisation throughout the world. The obsession with speed compelled human to compress time and space (Harvey 1992). Part of this compression involved reducing the time involved in delivering goods and services in order to achieve quick turnover and profits, and in turn, investing profits to finance other production opportunities and get quick profits from them. This ideology has now become a worldwide common currency. However, it has proved to be a nightmare in the event of COVID-19, when within the span of a few weeks the virus spread to every part of this earth. Thus, the very technology that is the means of transportation to create wealth is also the key facilitator in spreading the virus.

Technological advances have provided the bedrock to modernity and post-modernity but they are in fact a doubleedged sword. On the one hand, they have enabled human civilisation to practice the most sophisticated and advanced forms of life with greater opportunities to enjoy expressions of culture and material achievement. Yet, when thinking more soberly about this, obsession with technological development has led to the destruction of all sorts including the perpetuation of inequalities through the hegemony of exisiting digital divides that are perpetuated at the face of technological advances that remain the forte of few nations in the world. Since it is established that the roots to both the pandemics, that is, climate change and the rapid spread of COVID-19 in a short time span are attributed to technological advancements, it is pertinent to understand that even though it is not possible to reverse the damage done by them, it is still possible to handle these pandemics with the same technological advances if they are used properly and with vision. We will discuss this in more detail later in the paper.

\section{Pandemics: macro- and micro-landscapes}

Historically, pandemics have proven to include both macroand micro-characteristics. The current pandemics of climate change and COVID-19 are not that different from earlier 
catastrophes. In fact, both are located at the macro- and microlandscapes. At the macro-level, climate change can be located at the physical landscape of the earth. Climate change is governed by physical erosion of soil, landslides, deforestation, devastating hurricanes, droughts, heatwaves, floods, water and air contamination, ozone depletion, shrinking natural lands, and increasing levels of pollution just to name a few. At the micro-level, the impacts of these changing physical landscapes become evident in the social landscapes of individuals, families and communities. The erosion of natural ways of life, cultures, social networks (Barnett et al. 2016) along with these repercussions for health (Salvador et al. 2020) is leading to inferior and depleted living conditions (Sanson and Burke 2020; McMichael 2014) including the loss of non-material wealth created by diverse human activities. Vanishing from the world are cultural assets, indigenous knowledge systems, and local dialects and languages (Adger et al. 2009). These are just a few of the extreme disruptions that are experienced in the everyday micro-context due to the more visible macroclimate change events throughout the globe.

Akin to climate change, the COVID-19 pandemic also has both macro- and micro-features. At the macro-level, COVID19 is inflicting destruction on many countries around the globe, triggering a global crisis in health and slowing down the economy due to strict measures of quarantine (Harapan et al. 2020; Alam and Abdurraheem 2021; Alam et al. 2021a, b; Aktar et al. 2021). Barring a few nations, countries throughout the world are already economically stagnating in response to the pandemic. The World Trade Organization (WTO) and Organization for Economic Cooperation and Development (OECD) have asserted that the COVID-19 pandemic is the direst warning for the world economy since the 2008-2009 global financial crisis.

COVID-19 has proved to be a nightmare for small businesses with owners fearing that they will not be able to survive the pandemic (The Guardian 2020). Already, the pandemic has caused millions of people to suffer from unemployment, underemployment and live in poverty or subsistence levels (International Labor Organization 2020). The growing fear is that this will eventually lead the economy to a downward trend as these newly unemployed workers would no longer be able to afford to buy goods and services when industries start to cut their staff in order to compensate for lost sales. According to Baldwin and di Mauro (2020), the COVID-19 pandemic has impacted all of the world's major economies containing the G7 countries, who equally share $60 \%$ of the world's demand and supply (GDP), $65 \%$ of world manufacturing, and $41 \%$ of world exports in manufacturing. They define such changes and the falls in these percentages as 'macroeconomic flu' - a temporary destructive shock to supply and demand as well as triggering falls in output temporarily, monitored by a fast recovery and probably a full catch-up on the loss.
At the micro-level, the social distancing (now preferably called physical distancing) dimension of this pandemic is making everyone vulnerable irrespective of their social position. In the world's social landscapes, social distancing which is the 'new normal' has a high social cost. During the COVID-19 pandemic, the social costs are visible where the loss of social support and networks lead people to feelings of depression and anxiety which is further contributing to the loneliness pandemic (Palgi et al. 2020). Other micro-impacts include, but are not limited to, reduced human interactions through disruptions in social and cultural activities such as celebrations, limited leisurely pursuits due to lockdowns (Haleem et al. 2020), and more incidents of domestic violence in households where couples already prone to violence are psychologically distressed when forced for long indoor stays due to COVID-19 public health measures (Sharma and Borah 2020). In a nutshell, both pandemics (climate change and COVID-19) have reshaped our physical and social worlds. This calls for an urgent need to tackle both simultaneously.

\section{Forming differential experiences: structural inequalities exacerbated and reinforced}

The fissures of differential experiences rooted in and emanating from the historical structural inequalities are witnessed at the face of both pandemics. The scholarship of Ulrich Beck, a German sociologist and a risk theorist, echoes the hierarchical nature of the climate change pandemic. Beck (2010:175) argues: "[climate change] exacerbates existing inequalities of poor and rich". Wrathall et al. (2015) while discussing the gravely unequal impacts of climate change state: "Climate-linked stresses threaten to overwhelm regions such as small island developing states (SIDS), coastal settlements and semi-arid regions" (277). Wasko et al (2021) illustrate how the storm- and floodrelated catastrophes caused due to climate change result in economic losses for the people who lose their indigenous livelihood options. Lack of public awareness and unpreparedness of governments further feeds into global adversities (Ismail-Zadeh 2021). Thus, it would not be wrong to say that the brunt of destruction done to the climate by few is to be borne by many; the majority of people live in poverty and are already trapped in webs of structural inequalities.

To offer a couple of examples: air and vehicle pollution causes serious respiratory illness. In Third World countries, where urbanisation has led to depleted or unbuilt infrastructure, human health hazards are at a peak. Lack of healthy lifestyles due to the lack of walk or biking pathways, absence of public parks, etc., has greatly affected people living in urban slums with lifestyle illnesses such as diabetes, heart disease, respiratory problems, stroke, etc. (Mannucci and Franchini 2017). Similar evidence is found even in Europe, 
where 'unsustainable environments' have led to increased respiratory health issues including COVID-19 (Coccia 2020). Thus, a strong correlation is found between poor air quality and health and well-being of populations (Guzmán et al. 2022). Rich people have the option to choose between sedentary and healthy lifestyles having cleaner air quality and healthy food; the marginalised do not have that option, however. Elliot (2018:308) cautions us about "climate gentrification" which has been in the public lexicon for quite some time now. While quoting Keenan, Hill and Gubmer (2018), she notes how these authors suggest real estate investors in Miami-Dade County, Florida, which is vulnerable to hurricanes and floods, make investments in high-elevation areas to sell these properties to wealthy people that were historically home to poorer people. Thus, it makes visible how social factors of historical segregation along the lines of race and income intersect with climate gentrification.

Similar COVID-19 experiences are evident where preexisting inequities are sustained and reinforced for persons of colour (Dey and Sinha 2020), caste (Rahman 2020), disabled individuals (Goggin and Ellis 2020), and a variety of other vulnerable groups. Marginalised groups are particularly susceptible to COVID-19 exposure due to their preexisting conditions of poverty, bad housing, and low income. In other words, they are already victims of the wealthier people of society treating them equally. It is at this moment in time that we believe it is worthwhile to stop the pattern of keeping vulnerable in their current state.

\section{Exploring possibilities and a way forward}

To begin, we propose meditating on the key problems that haunt the current world, namely: why are certain groups in society so vulnerable and marginalised? When a disaster strikes, whose consequences are the most significant? And why is that? When the earth is most vulnerable, even the wealthiest and most powerful individuals will not be left safe and secure; therefore, who should be accountable for taking the initial basic efforts toward planet preservation?

Taking the third question first, we believe that everyone, whether, rich or poor, is tied with the common thread of pain and suffering when pandemics happen. Though the intensity differs due to structural inequalities as already explained in the previous sections, it becomes everybody's project to make their contribution in dealing with the calamities that are irreversible now and making only a small effort to stop future disasters. We do recognise, however, that making these small efforts by everyone might not be really possible in some contexts. For example, the COVID-19 prevention through vaccination has been unequal in the world with Africa having less than 10 per cent population which is vaccinated so far. Likewise, for the climate change pandemic, the developed world is to bear more responsibility as they have the technological means to find green solutions that can save the earth. In this vein, endorsing the UN Climate Change Conference in Glasgow (COP26), there is certainly a dire need for all countries to adopt rigorous transparency and accountability mechanisms (United Nations 2021). This would encourage the industries to demonstrate that they are doing serious efforts to achieve the environmental targets set by them. One way to demonstrate this is yearly public disclosure of measurable environmental goals to the general public, global citizens, and various levels of their own government officials. Overall, there is no one size fits all approach to reaching a solution; consequently, with a broad-brush stroke, we propose exploring the following possibilities.

First, it is time to acknowledge and apply in practice Mills' (1959) notion of Sociological Imagination. According to Mills, personal troubles are public issues. In other words, the vulnerabilities and marginalisation are historically rooted in the broader structures of power and oppression. An individual must not blame him/herself for their experiences. Instead, it is the systems of government, education, religion, etc., that are the cause of one's experiences the way in which they are formed. At the level of the marginalised groups 'collective action' is the need to take the initiative to bring about change in those practices that are harmful to the climate, for example. One small way of doing so could be conserving energy, water, and removing garbage from their streets. Likewise, in these COVID-19 times, there is a greater possibility of mistakenly taking physical distancing as social distancing. People must find ways to keep themselves socially connected, which is possible through digital technologies. Locating again and applying the lens of sociological imagination, in order to defeat the COVID-19 impact, it is pertinent for the governments to win the trust of the dominant majority, that is, the marginalised, who are not part of the policymaking processes but are nonetheless the most affected. Furthermore, there is a strong need to develop such tools that would allow having new insights into the causes of climate change and their systemic impacts on health and other aspects of everyday life (Beard et al. 2021; Kong 2021; García Casañas 2021). Having said that, the governments must reduce the digital divide by investing in it so that everyone can afford modern technology, use it and make them tech-savvy. This has the potential to consequently reduce inequalities by allowing them to reap the fruits of online businesses and improve their economic conditions.

Second, what is important is the applicability of the concept of "loss", a competing view to "sustainability". Rebecca Elliot in her recent work on climate change coined the idea of "loss". By locating the idea of "loss" she aims to break up the conventional silo of research produced in environmental sociology. Her key argument anchored in the sociology of loss establishes a point of departure from the idea 
of "sustainability" as the only way of saving the planet's climate. Her argument is rested on the central tenet of taking into account and contemplating "what does, will, or must disappear rather than what can or should be sustained" (Elliot 2018: 301). Reliance on this notion of loss can help us embed healthy practices in our daily lives. For example, if as individuals, we accept the loss of physical interactions with neighbours and friends in these COVID-19 times, then we will know what we will be able to sustain, i.e. healthy lungs, and no unnecessary burden on the world's healthcare systems. Furthermore, reduced use of transport during lockdowns amidst COVID-19 has resulted in the appreciation of good air quality due to reduced carbon emissions (Kumar et al. 2022).

Third, the solution to global pandemics lie in local contexts, whilst acknowledging the lesson learnt from a comparative perspective (Dasgupta et al. 2022). For example, considering the disparity between the efforts of developed and developing countries, whether it is to control COVID19 spread or the adverse impacts of climate change, the focus should be on existing indicators of vulnerability (such as poverty, use of available resources, technological know-how, and the local governance systems) and their intersections with policies pertaining to health and climate change.

Finally, alluding to science in findings solutions to COVID-19 and climate change, the adoption of a smart healthcare system offers a joint solution to mitigate a few of the impacts of both the pandemics. "Smart healthcare is a health service system that uses technology such as wearable devices, IoT, and mobile internet to dynamically access information, connect people, materials and institutions related to healthcare, and then actively manages and responds to medical ecosystem needs in an intelligent manner." (Tian et al. 2019: 62). In the developed world, it is already implemented for quite some time now. In a recent study, Jabeen et al. (2021) did research using a secure Monte Carlo-based COVID-19 detection framework for smart healthcare. They suggested tracking breathing rate, ECG levels, body temperature and other COVID-19-related health conditions that would be detected through the sensory device by people themselves.

Even though in the developing countries people are poor, and poverty is further exacerbated because of loss of livelihoods caused by lockdowns and ill-health due to COVID- 19 . Nonetheless, implementing a few affordable yet accessible aspects of a smart health system to the masses have the potential to reverse these impacts. This is also evident from a brief SWOT analysis of implementing smart healthcare in developing countries like Africa. The key strength of it in developing countries is the speedy delivery of an individual's health data to the medical servers through the blue tooth device they would wear. The weakness however is the danger of hacking the wireless data in case the medical servers are attacked. The opportunities for implementing the smart health systems exist in developing countries since it is a cheaper option for the masses to access healthcare, while saving the transportation and other costs which they are to incur in the traditional healthcare system of accessing the hospitals or clinics in person. The threat however is rooted in the social behaviour of people, which needs to be changed in order to make them shift to this new system.

In summary, investment in these devices would result in fewer hospitalisations and thus a lower likelihood of COVID19 dissemination. As a result, this would improve the environment by lowering the number of landfills that require PPE suits and masks. These possibilities may be the start of a charter for a new world that is both safe and enjoyable for everyone. Individuals, communities, and governments may work together to close the gaps in society that contribute to inequities, disasters, and pandemics.

\section{Conclusion}

This study's goal was to synthesise evidence-based consequences of both climate change and pandemics. The study's main conclusions are compared to notable modern social theorists. The analysis reveals three interrelated themes: technological improvements have harmed vulnerable individuals; pandemics include macro- and micro-features; and systemic inequities have harmed vulnerable people. Finally, we believe that tackling COVID-19 and climate change requires a community effort, based on local circumstances and recognising developed-world lessons. Acknowledging the presence of multiple social issues, policymakers may build strategic policies that help mitigate the effects of global catastrophes.

Authors' contributions $\mathbf{Z W}$ conceptualised, conducted the analysis, and wrote the first draft. MMA conceptualised, reviewed and improved the overall manuscript. AQA reviewed, edited, and formatted the manuscript.

\section{Declarations}

Ethical approval Not applicable.

Consent to participate Not applicable.

Consent to publish Not applicable.

Competing interests The authors declare that they have no competing interests. 


\section{References}

Abramowitz S (2017) Epidemics (Especially Ebola). Annu Rev Anthropol 46:421-445. https://doi.org/10.1146/annur ev-anthro-102116-041616

Adger WN, Dessai S, Goulden M, Hulme M, Lorenzoni I, Nelson DR, Naess LO, Wolf J, Wreford A (2009) Are there social limits to adaptation to climate change? Clim Change 93:335-354. https:// doi.org/10.1007/s10584-008-9520-Z

Aktar MA, Alam MM, Al-Amin AQ (2021) Global economic crisis, energy use, CO2 emissions and policy roadmap amid COVID-19. Sustain Prod Consum 26:770-781. https://doi.org/10.1016/j.spc. 2020.12.029

Alam MM, Abdurraheem II (2021) COVID-19 and the financial crisis in the sports sector around the World. Sport Soc. https://doi.org/ 10.1080/17430437.2021.1979964

Alam MM, Fawzi AM, Islam MM, Said J (2021a) Impacts of COVID19 pandemic on national security issues: Indonesia as a case study. Secur J. https://doi.org/10.1057/s41284-021-00314-1

Alam MM, Wei H, Wahid ANM (2021) COVID-19 outbreak and sectoral performance of the Australian stock market: an event study analysis. Aust Econ Pap 60(3):482-495 (https://onlinelibrary. wiley.com/doi/10.1111/1467-8454.12215)

Albert MJ (2021) The climate crisis, renewable energy, and the changing landscape of global energy politics. Alternatives. https://doi. org/10.1177/03043754211040698

Baldwin R, di Mauro BW (eds) (2020) Economics in the time of COVID-19. A VoxEU.org Book, Centre for Economic Policy Research, London. Available from: https://voxeu.org/system/files/ epublication/COVID-19.pdf. Accessed 14 Jan 2021

Barnett J, Tschakert P, Head L, Adger WN (2016) A science of loss. Nat Clim Chang 6:976-978. https://doi.org/10.1038/nclim ate 3140

Beard SJ, Holt L, Tzachor A, Kemp L, Avin S, Torres P, Belfield H (2021) Assessing climate change's contribution to global catastrophic risk. Futures 127:102673. https://doi.org/10.1016/j.futur es.2020.102673

Beck U (2010) Remapping social inequalities in an age of climate change: for a cosmopolitan renewal of sociology. Glob Netw 10:165-181. https://doi.org/10.1111/j.1471-0374.2010.00281.x

Bodansky D (2016) The Paris climate change agreement: a new hope? Am J Int Law 110:288-319. https://doi.org/10.5305/amerjintelaw. 110.2 .0288

Camus A (1948) The plague. Hamish Hamilton, London

Chakraborty I, Maity P (2020) COVID-19 outbreak: migration, effects on society, global environment and prevention. Sci Total Environ 728:138882. https://doi.org/10.1016/j.scitotenv.2020.138882

Christoff P (2016) The promissory note: COP 21 and the Paris climate agreement. Environ Polit 25(5):765-787. https://doi.org/10.1080/ 09644016.2016.1191818

Coccia M (2017) Disruptive firms and industrial change. J Econ Soc Thought 4(4):437-450. https://doi.org/10.1453/jest.v4i4.1511

Coccia M (2020) How (Un)sustainable environments are related to the diffusion of covid-19: the relation between coronavirus disease 2019, air pollution, wind resource and energy. Sustain 12:1-12. https://doi.org/10.3390/su12229709

Crenshaw K (1989) Demarginalizing the intersection of race and sex: a black feminist critique of antidiscrimination doctrine, feminist theory and antiracist politics. Univ. Chic. Leg. Forum 140, article 8

Dasgupta S, Wheeler D, Bandyopadhyay S, Ghosh S, Roy U (2022) Coastal dilemma: climate change, public assistance and population displacement. World Dev 150:105707. https://doi.org/10. 1016/j.worlddev.2021.105707
Dasgupta S, Crunkhorn R (2020) A History of pandemics over the ages and the human cost. The Physician 6. https://doi.org/10.38192/1. 6.2 .1

De La Peña L, Guo R, Cao X, Ni X, Zhang W (2022) Accelerating the energy transition to achieve carbon neutrality. Resour Conserv Recycl 177:105957. https://doi.org/10.1016/j.resconrec.2021. 105957

Demiris G, Oliver DP, Washington KT (2019) Defining and analyzing the problem. Behav Interv Res Hosp Palliat Care 27-39. https:// doi.org/10.1016/B978-0-12-814449-7.00003-X

Dey T, Sinha A (2020) Ethnicity and COVID-19 - A commentary on "World Health Oganization declares global emergency: A review of the 2019 novel coronavirus (COVID-19). Int J Surg 83:75-76. https://doi.org/10.1016/j.ijsu.2020.08.046

Elliott R (2018) The sociology of climate change as a sociology of loss. Eur J Sociol 59:301-337. https://doi.org/10.1017/S0003 975618000152

Falkner R (2016) A minilateral solution for global climate change? on bargaining efficiency, club benefits, and international legitimacy. Perspect Polit 14:87-101. https://doi.org/10.1017/s153759271 5003242

Farid M, Keen M, Papaioannou M, Parry I, Pattillo C, Ter-Martirosyan A (2016) After Paris: fiscal, macroeconomic and financial implications of global climate change. Staff Discuss Notes 16:1. https:// doi.org/10.5089/9781513506562.006

GarcíaCasañas C (2021) Don't they understand climate science? Reflections in times of crisis in science and politics. Public Underst Sci 30:947-961. https://doi.org/10.1177/0963662521 1011882

Giddens A (1991) The consequences of modernity. Stanford University Press

Goggin G, Ellis K (2020) Disability, communication, and life itself in the COVID-19 pandemic. Heal Sociol Rev 29:168-176. https:// doi.org/10.1080/14461242.2020.1784020

Golechha M (2020) COVID-19, India, lockdown and psychosocial challenges: what next? Int J Soc Psychiatry 66:830-832. https:// doi.org/10.1177/0020764020935922

Guzmán P, Tarín-Carrasco P, Morales-Suárez-Varela M, Jiménez-Guerrero P (2022) Effects of air pollution on dementia over Europe for present and future climate change scenarios. Environ Res 204:112012. https://doi.org/10.1016/j.envres.2021.112012

Haleem A, Javaid M, Vaishya R (2020) Effects of COVID-19 pandemic in daily life. Curr Med Res Pract 10:78-79. https://doi.org/10. 1016/j.cmrp.2020.03.011

Harapan H, Itoh N, Yufika A, Winardi W, Keam S, Te H, Megawati D, Hayati Z, Wagner AL, Mudatsir M (2020) Coronavirus disease 2019 (COVID-19): a literature review. J Infect Public Health. https://doi.org/10.1016/j.jiph.2020.03.019

Harvey D (1992) The condition of postmodernity: an enquiry into the origins of cultural change. Wiley-Blackwell

Holt LA (2021) Why shouldn't we cut the human-biosphere umbilical cord? Futures 133:102821. https://doi.org/10.1016/j.futures. 2021.102821

IEA (2015) Energy and climate change: world energy outlook special report. Available from: https://webstore.iea.org/weo-2015-speci al-report-energy-and-climate-change . Accessed 14 Jan 2021

International Labor Organization (2020) Almost 25 million jobs could be lost worldwide as a result of COVID-19, says ILO. Available from: https://www.ilo.org/global/about-the-ilo/newsroom/news/ WCMS_738742/lang--en/index.htm. Accessed 14 Jan 2021

IPCC (2014) Climate change 2014: synthesis report. Cambridge University Press, Cambridge

Ismail-Zadeh A (2021) Poor planning compounded European flooding catastrophes. Nature 598(7879):32 
Jabeen T, Jabeen I, Ashraf H (2021) A secure Monte Carlo based COVID-19 detection framework with edge computing for smart healthcare, IEEE ACCESS, pp. 1-18

Keenan JM, Hill T, Gumber A (2018) Climate gentrification: from theory to empiricism in Miami-Dade County, Florida. Environ Res Lett 13(5):054001. https://doi.org/10.1088/1748-9326/aabb32

Khalid A, Ali S (2020) COVID-19 and its challenges for the healthcare system in Pakistan. Asian Bioeth Rev 12:551-564. https://doi.org/ 10.1007/s41649-020-00139-x

Kong F (2021) Understanding and strengthening the role of catastrophe lottery in catastrophe risk transfer system. J Contingencies Cris Manag 29:226-228. https://doi.org/10.1111/1468-5973.12338

Kumar A, Singh P, Raizada P, Hussain CM (2022) Impact of COVID19 on greenhouse gases emissions: a critical review. Sci Total Environ. https://doi.org/10.1016/j.scitotenv.2021.150349

Laurencin CT, Walker JM (2020) A pandemic on a pandemic: racism and COVID-19 in blacks. Cell Syst 11:9-10. https://doi.org/10. 1016/j.cels.2020.07.002

Le Quéré C, Andrew RM, Canadell JG, Sitch S, Korsbakken JI, Peters GP, Manning AC, Boden TA, Tans PP, Houghton RA, Keeling RF, Alin S, Andrews OD, Anthoni P, Barbero L, Bopp L, Chevallier F, Chini LP, Ciais P, Currie K, Delire C, Doney SC, Friedlingstein P, Gkritzalis T, Harris I, Hauck J, Haverd V, Hoppema M, Klein Goldewijk K, Jain AK, Kato E, Körtzinger A, Landschützer P, Lefèvre N, Lenton A, Lienert S, Lombardozzi D, Melton JR, Metzl N, Millero F, Monteiro PMS, Munro DR, Nabel JEMS, Nakaoka S, O’Brien K, Olsen A, Omar AM, Ono T, Pierrot D, Poulter B, Rödenbeck C, Salisbury J, Schuster U, Schwinger J, Séférian R, Skjelvan I, Stocker BD, Sutton AJ, Takahashi T, Tian H, Tilbrook B, van der Laan-Luijkx IT, van der Werf GR, Viovy N, Walker AP, Wiltshire AJ, Zaehle S (2016) Global carbon budget 2016. Earth Syst Sci Data 8:605-649. https://doi.org/10. 5194/essd-8-605-2016

Limaye VS, Max W, Constible J, Knowlton K (2019) Estimating the health-related costs of 10 climate-sensitive U.S. events during 2012. GeoHealth 3:245-265. https://doi.org/10.1029/2019G H000202

Lum ME, McMillan AJ, Brook CW, Lester R, Piers LS (2009) Impact of pandemic (H1N1) 2009 influenza on critical care capacity in Victoria. Med J Aust 191:502-506. https://doi.org/10.5694/j. 1326-5377.2009.tb02914.x

Lupton D (2020) Special section on 'Sociology and the Coronavirus (COVID-19) Pandemic.' Heal Sociol Rev 29:111-112. https://doi. org/10.1080/14461242.2020.1790919

Mannucci PM, Franchini M (2017) Health effects of ambient air pollution in developing countries. Int J Environ Res Public Health. https://doi.org/10.3390/ijerph14091048

Marmot M (2020) Society and the slow burn of inequality. Lancet 395:1413-1414. https://doi.org/10.1016/S0140-6736(20)30940-5

McMichael AJ (2014) Climate change and children: health risks of abatement inaction, health gains from action. Children (Basel, Switzerland) 1:99-106. https://doi.org/10.3390/children1020099

Mills C (1959) The sociological imagination. Oxford University Press, New York

Palgi Y, Shrira A, Ring L, Bodner E, Avidor S, Bergman Y, CohenFridel S, Keisari S, Hoffman Y (2020) The loneliness pandemic: Loneliness and other concomitants of depression, anxiety and their comorbidity during the COVID-19 outbreak. J Affect Disord 275:109-111. https://doi.org/10.1016/j.jad. 2020.06.036

Paré G, Kitsiou S (2017) Chapter 9 methods for literature reviews. In: Lau F, Kuziemsky C, editors. Handbook of eHealth evaluation: an evidence-based approach [Internet]. Victoria (BC): University of Victoria. Available from: https://www.ncbi.nlm.nih.gov/books/ NBK481583/
Patz JA, Stull VJ, Limaye VS (2020) A low-carbon future could improve global health and achieve economic benefits. JAMA: J Am Med Assoc 323:1247-1248. https://doi.org/10.1001/jama. 2020.1313

Prainsack B (2020) Solidarity in times of pandemics. Democr Theory 7:124-133. https://doi.org/10.3167/dt.2020.070215

Rahman SY (2020) 'Social distancing' during COVID-19: the metaphors and politics of pandemic response in India. Heal Sociol Rev 29:131-139. https://doi.org/10.1080/14461242.2020.1790404

Renjen P (2020) Resilient leadership responding to COVID-19, Deloitte Insights. Deloitte. Available from: https://www2.deloi tte.com/global/en/insights/economy/covid-19/heart-of-resilientleadership-responding-to-covid-19.html. Accessed 14 Jan 2021

Reuters (2020) Germans stage protests against lockdown measures, social distancing rules, Available from: https://www.reuters.com/ article/us-health-coronavirus-germany-protests/germans-stageprotests-against-lockdown-measures-social-distancing-rulesidUKKBN22S0MS? edition-redirect=uk. Accessed 14 Jan 2021

Rogelj J, den Elzen M, Höhne N, Fransen T, Fekete H, Winkler H, Schaeffer R, Sha F, Riahi K, Meinshausen M (2016) Paris Agreement climate proposals need a boost to keep warming well below $2{ }^{\circ} \mathrm{C}$. Nature 534:631-639. https://doi.org/10.1038/nature18307

Salvador C, Nieto R, Linares C, Díaz J, Gimeno L (2020) Effects of droughts on health: diagnosis, repercussion, and adaptation in vulnerable regions under climate change. Challenges for future research. Sci Total Environ 703:134912. https://doi.org/10.1016/j. scitotenv.2019.134912

Sanson AV, Burke SEL (2020) Climate change and children: an issue of intergenerational justice. In: Balvin N, Christie DJ (eds) Children and peace: from research to action. Springer International Publishing, Cham, pp 343-362. https://doi.org/10.1007/978-3030-22176-8_21

Scambler G (2020) Covid-19 as a 'breaching experiment': exposing the fractured society. Heal Sociol Rev 29:140-148. https://doi.org/10. 1080/14461242.2020.1784019

Sharma A, Borah SB (2020) Covid-19 and domestic violence: an indirect path to social and economic crisis. J Fam Violence. https:// doi.org/10.1007/s10896-020-00188-8

Shoman H, Karafillakis E, Rawaf S (2017) The link between the West African Ebola outbreak and health systems in Guinea, Liberia and Sierra Leone: a systematic review. Global Health 13:1. https://doi. org/10.1186/s12992-016-0224-2

Siekmans K, Sohani S, Boima T, Koffa F, Basil L, Laaziz S (2017) Community-based health care is an essential component of a resilient health system: evidence from Ebola outbreak in Liberia. BMC Public Heal 17:84. https://doi.org/10.1186/s12889-016-4012-y

The Guardian (2020) ECB Asset Purchase Programme Boosts Euro [accessed on 20 March, 2020]. Available from: https://www.thegu ardian.com/world/2020/mar/19/ecb-asset-purchase-programmeboosts-euro . Accessed 14 Jan 2021

The Tribune (2020) Covert oppression in the times of Covid: The Tribune India, Available from: https://www.tribuneindia.com/ news/comment/covert-oppression-in-the-times-of-covid-88173. Accessed 14 Jan 2021

Tian S, Yang W, Grange JML, Wang P, Huang W, Ye Z (2019) Smart healthcare: making medical care more intelligent. Glob Heal $\mathrm{J}$ 3:62-65. https://doi.org/10.1016/J.GLOHJ.2019.07.001

UN (2020) Acts of kindness spread amid COVID-19 outbreak as UN acts to counter threat, United Nations. Available from: https:// www.un.org/en/coronavirus-disease-covid-19/acts-solidarityspread-amid-covid-19-outbreak-un-continues-counter. Accessed 14 Jan 2021

UN (2021) COP26: Together for our planet, United Nations. Available from: https://www.un.org/en/climatechange/cop26. Accessed 13 Dec 2021 
Urry J (2016) What is the future? Polity, Cambridge

Wasko C, Sharma A, Pui A (2021) Linking temperature to catastrophe damages from hydrologic and meteorological extremes. J Hydrol 602:126731. https://doi.org/10.1016/j.jhydrol.2021. 126731

Wrathall D, Oliver-Smith A, Fekete A, Gencer E, Lepana M, Sakdapolrak P (2015) Problematising loss and damage. Int J
Glob Warm 8(274):294. https://doi.org/10.1504/JJGW.2015. 071962

Publisher's note Springer Nature remains neutral with regard to jurisdictional claims in published maps and institutional affiliations. 